\title{
THE IMPORTANCE OF INTERCULTURAL COMMUNICATIVE COMPETENCES IN ENGLISH CLASSES ON THE CONTEXT OF CURRENT MIGRATION WAVES
}

\author{
Ana María Santana¹, Blanca Lucia Cely²
}

\begin{abstract}
:
The study of intercultural communicative competences (ICC) in the exercise of teaching a foreign language has turned into a vibrant line of research in recent years. It is relevant to promote ICC in English classes to develop awareness, acceptance and respect among members from other cultures and backgrounds, especially on the context of current migration waves around the world, due to the impact of globalization and internationalization in education. Scholars have been talking about intercultural competences and their importance: why it is worth reflecting on their inclusion of ICC in the EFL classroom and the way they are conceived, as well as their contributions to the human being's development.

This paper focuses on a literature review of the definition of intercultural competencies and the conceptions of some scholars who have hardly worked on them and made contributions for teachers of English. Due to the strong relationship between teaching a foreign language and intercultural communicative competences in the EFL classes, it is relevant to clarify the notion of culture, intercultural competence and intercultural communicative competence; all of these concepts are presented in order to clarify their impact in the classroom.
\end{abstract}

Keywords: culture, intercultural communicative competence, intercultural competence, migratory waves

Historial del artículo:

Fecha de recibido: 15-12-2020 - Fecha de aceptado: 10-05-2021

(C) 2021 Fundación Universitaria Juan N. Corpas (FUJNC).

Artículo Open Access bajo la Licencia Creative Commons Atribución-NoComercial-Compartirlgual 4.0 Internacional.

DOI: 10.26752/revistaparadigmassh.v3i1.519

\footnotetext{
${ }^{1}$ Undergraduate student of the bachelor degree with experience in the field of teaching English as a foreign language. Her research interest is focused in interculturality and globalization in education.

${ }^{2}$ Foreign languages teacher with a master degree in Applied Linguistics to teach English as a foreign language; currently, she is a student of a Ph.D. in Education at Universidad Iberoamericana Internacional in Mexico. Her interests in research are focused on teaching and teachers training. She is doing a research project that aims to investigate the training foreign languages teachers have had to attend people with different capacities.
} 


\section{LA IMPORTANCIA DE LAS COMPETENCIAS COMUNICATIVAS INTERCULTURALES EN LAS CLASES DE INGLÉS EN EL CONTEXTO DE LAS ACTUALES OLAS MIGRATORIAS}

Ana María Santana ${ }^{1}$, Blanca Lucia Cely²

\section{Resumen:}

El estudio de las competencias comunicativas interculturales (CCI) en la enseñanza de una lengua extranjera se ha convertido en una línea de investigación vibrante en los últimos años. Es relevante promover las CCl en las clases de inglés para desarrollar conciencia, aceptación y respeto entre miembros de otras culturas y orígenes, en el contexto de las olas migratorias actuales alrededor del mundo, debido al impacto de la globalización e internacionalización en la educación. Los académicos llevan tiempo hablando de las competencias interculturales y de su importancia; por eso, vale la pena reflexionar sobre su inclusión en el aula de inglés como lengua extranjera y la forma en que se conciben, así como sus contribuciones al desarrollo de los seres humanos.

Este artículo se centra en una revisión de la literatura sobre la definición de competencias interculturales y las concepciones de algunos académicos que han trabajado fuertemente en ellas y han hecho aportes para profesores de inglés. Debido a la fuerte relación entre la enseñanza de una lengua extranjera y las competencias comunicativas interculturales en las clases de EFL, es relevante aclarar la noción de cultura, competencia intercultural y competencia comunicativa intercultural; todos estos conceptos se presentan con el fin de aclarar su impacto en el aula.

Palabras clave: cultura, competencia comunicativa intercultural, competencia intercultural, olas migratorias. 


\section{Introduction}

At the present time, the world is becoming a globalized society, due to the current cultural migrations, the widespread use of English around the world, the technological era and the people's necessity to apply an international communication; it requires that individuals possess certain competences to establish cross-cultural relationships in order to develop their intercultural awareness that enables individuals to discover and understand the different cultural manifestations around the world and other people's backgrounds. New generations are crossing cultural borders because of spread of English as an international language that demands people learn English as a requirement to access to better job opportunities.

Mastering English as a foreign language is one of the competence required nowadays to build cross cultural communication and purposeful knowledge, between individuals and communities around the world. This fact has made that in Colombia, as in many other countries around the world, it has been implemented policies to include bilingualism in education. In Colombia, the Ministry of Education (MEN) has been working for more than forty years on the implementation of curricular documents and laws to accomplish this goal.

The bilingualism law by MEN delivered in 2015 is the most recent one. This law promotes learning English as foreign language in order to support globalization processes by enhancing individual's language competences. The adoption of the Common European Framework of Reference for Languages by the Council of Europe (2001) into the bilingualism law gave much importance to cultural aspects in foreign language education (Reid, 2015). One of them is to promote the intercultural communicative competence (ICC) in the English classroom.
On the other hand, the current migration waves around the world make teachers increase awareness ICC, because education is a social experience in which people since their youth are getting to know each other to improve and enriching relationships with others, acquiring and renewing the basis of theoretical and practical knowledge (Delors, 1996, p. 19). Educative context constitutes the permanent opportunity for human beings to advance and strengthen their social and individual competencies.

Hence, learning culture is essential for life because human beings who interact with different cultures become an active recipient and can build and strengthen personality, receiving what the environment offers to cope with the social relationships that people maintain. For that reason, the main objective of learning a language should not be defined as the acquisition of communicative competences; it means the mere development of communicative skills. Somewhat, it should be defined in terms of the intercultural competence that implies linguistic and social skills, knowledge and attitudes needed to communicate effectively and appropriately in real situations.

Meyer (1991) proposes the intercultural competence as an ability to behave satisfactorily when confronted with actions, attitudes and expectations of people from other cultures and languages supports. Others authors, such as Byram \& Zarate (1997) and Tarone \& Swain (1995), define ICC as the comprehension and consciousness of the socio-cultural cannon; ICC also refers to the receptiveness of the participants of a speech community to model their speech according to the context in which they are immersed (Tarone \& Swain, 1995).

In this way, intercultural dimension in teaching a foreign language has become a special concern for teachers and researchers. Over the past few decades, there were important advances that have transformed the teaching 
performance; one of them is to recognize the cultural dimension as a key component in the curriculums. Based on this concern, different studies have been carried out about intercultural communicative competence and its relevance nowadays.

It is important to clarify that in the development of ICC learners should, first, explore and understand their own culture and the features that make part of it such as: values, expectations, traditions, customs, and rituals they unconsciously participate in; then to be prepared to reflect upon the values, expectations, and traditions of other cultures with a degree of intellectual objectivity. Straub (1999) also applied into teacher ICC knowledge and practices. Abrams (2002) states that foreign language teachers should help students to organize their own cultural symbols and offer learners opportunities to develop skills and promotes cultural curiosity which is linked with ICC.

Although, researchers have studied the ICC into the field of education and they found evidence of some deficiencies in this area, not only in Colombia, but also around the world. Barletta (2009, p. 143), for example, states teachers have a limited notion of culture and culture teaching and it is because they have misconceptions about the teaching of communicative competence. In some cases, teaching culture has occupied a secondary place in the English classroom. However, it is required to integrate language and culture to develop an assertive development of communicative competence.

Intercultural communicative competence is a key ability that must be promoted when foreign learners are learning a language because ICC encodes the main function of learning a foreign language, which is performing speech and acts in different scenarios without using ambivalent language. The main component of having cultural awareness is having tenderness of the differences between individuals and people from other countries or backgrounds. So the intercultural communicative competence encloses cultural awareness and the consciousness of the language in use.

On the other hand, the implementation of ICC helps students to understand customs and beliefs of other cultures and improve values such as tolerance and respect when they have to interact with people coming from other cultures or visit other countries and places with differences, in manners and cultures. It also promotes to value our own culture and make others understand it and value it too.

There is not enough evidence about intercultural communicative competences and teachers' practices in English classes in the context of current migration waves based on the previous studies findings. This overview confirms the existing lack of awareness about the ICC in different learning environments and its need to be developed or reinforced. The information presented in this paper provides a first attempt to reflect on our teaching performance by knowing how ICC promotes humanistic competences and support learner's development in a foreign language.

\section{Theoretical framework}

This part includes the conceptual referents or theoretical developments that conceptualize the topic under the glance of different authors and its corresponding definitions developed along the time and how those areas have been introduced into English as a foreign language field in foreign language education in Colombia. It includes the historical development of the main concepts that are immersed into this research. Concepts such as: culture (C), intercultural competence (IC), communicative competence (CC) and intercultural communicative competence (ICC). 


\section{An attempt to define culture}

Culture has been part of human beings since the beginning of the times. It allows communities to exchange knowledge in order to build their behavioral patterns and their communication needs. It cannot be defined by a unique point of view because there are different conceptions of it, depending on the area of study, participants and backgrounds in which it is immersed.

Susan Wright (1998) in her work "The Politicization of 'Culture' cited Tylor" defines culture as a mosaic that includes beliefs, norms, values, costumes, and other skills and acquired patterns an individual gets when is member of the society. Also, Fowler (1986), cited by Claire Kramsch (2001, p. 42), in his book Context and Culture in Language Teaching, stating: "The context of culture is the community's store of established knowledge that consists of structures of expectations that allow people to make sense of the world around them".

According to other researchers, culture builds visible and invisible patterns, obtained by behavior and mediates by ideograms. It constitutes the accomplishment of human groups, evolving their archetypes in artifacts. The nucleus of culture consists of traditional long-established ideas and the fixed values and beliefs (Kroeber \& Kluckhohn, 1952; cited by Adler, 1997, p. 14). In addition, Spencer-Oatey, (2008) provides a newer definition of culture. He states:

Culture is a fuzzy set of basic assumptions and values, orientations to life, beliefs, policies, procedures and behavioral conventions that are shared by a group of people, and that influence (but do not determine) each member's behavior and his/her interpretations of the "meaning" of other people's behavior.

Finally, another definition of culture can be shown in the figure 1. There are many aspects of what constitutes "culture", as illustrated by the Iceberg Model (Hall, 1976). It distinguishes between the components of culture (surface culture) and those that are not evident at first sight (deep culture).

Figure 1. Iceberg model

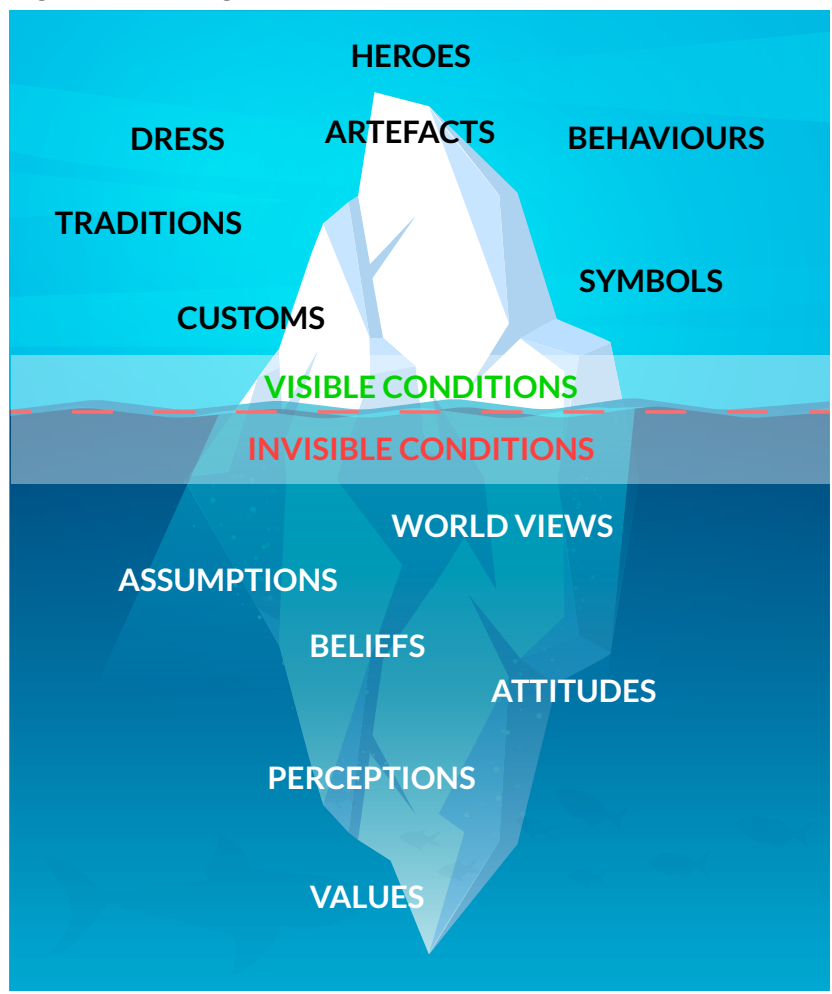

Source: Hall (1976).

Bearing in mind previous information, there are two main distinctions about culture. The one called CMLA (music, literature and art of a country) and the second one called CBBV (beliefs, behaviors and values). Those are the artifacts immersed in culture. Languages include culture as a key point, because it is one of the artifacts used by cultures to set effective communication and interaction. It encodes cultural knowledge known as the cultural set of values and traditions of a specific group of people and then this process is known as cultural learning, for example, when soft skills are given as subject of study or brought to reflection during the lesson.

Byram et al. (2002) lays some foundations in this field by declaring that cultural learning is kept by individuals their whole life. They carry this cultural knowledge stained from one social group to another which has their own beliefs, 
values and behavior (Paige et al., 2003). Regarding language education, it's exposed that intercultural language has been considered to fulfill cultural changes, acknowledging an interrelation between language and culture. Culture learning encodes the practice of acquiring culture-specific and culture-general knowledge, a set of beliefs, attitudes, skills and tradition to allow individuals to portrait real interaction and fruitful communication with others.

Culture changes and it is visible in daily life interaction, being appreciable when individuals expose themselves to contexts in which cultural artifacts are challenged. When cultural artifacts are challenged either by direct intercultural experience or by learning experience culture mutates and those mutations are also culture learning actions. In such a manner, individuals cooperate consciously or unconsciously to build communicative bridges between different cultures by getting cultural knowledge and by being aware of others culture artifacts such as traditions, values, beliefs, language and behavior.

\section{Intercultural competence}

As mentioned above, culture artifacts were and are still used to build communication between cultures and allow interaction with different people in diverse contexts by keeping cultural awareness and sufficient knowledge about it to promote diversity. The mix and application of those aspects of real life could refer to a specific competence individual obtain, develop get through cultural encounters with others. This competence is denominated as the intercultural competence.

This means that intercultural competence is "a set of abilities in which people use to adapt themselves to cultures and lifestyles to effectively communicate with others who are linguistically and culturally different from oneself" (Fantini \& Tirmizi, 2006, p. 12). In the same tendency, Unesco (2013) states that intercultural competences aim at freeing people from their own logic and cultural idioms in order to engage with others and listen to their ideas, which may involve belonging to one or more cultural systems, particularly if they are not valued or recognized in a given sociopolitical context. (p. 5)

To reinforce the idea that was mentioned before, the definition given by Byram \& Zarate (1997) of intercultural competence is:

The speaker's ability to interact with people from different languages or countries drawing upon their knowledge about their own culture and that of the others, taking into account their attitudes of interest in otherness and skills in interpreting, relating and discovering. (p. 38)

Authors such as Bennett (1998) explain the steps people took before a complete development of intercultural competences: 1) A strong adherence to a single culture-bound view of reality in people only views their culture as valuable. 2) Confronting differences, in which people tend to use stereotypes to refer to others, assuming negative positions towards other. 3) Seeing commonalities, people notice the unfair positions they have assumed against others and they start reflecting to change those behaviors in order to accept others culture. 4) Intercultural understanding, people recognize other points of view and they get familiarized with them by accepting them as inherent part of culture. 5) Intercultural competence, at this stage people develop the competence in which they learn how to communicate with others without judging their culture and promoting multicultural dialogues.

Since intercultural competence is used to promote dialogue between cultures in order to build knowledge, values and interaction, it is required to support the development of this competence in today's society to foster cultural diversity in a convoluted world; it is not sufficient when accepting other's differences as valid. Likewise, to encourage a dialogue between cultures is compulsory to develop communica- 
tive competences in which the cultural aspect commands the generation of the intercultural communicative competence to reach this aim.

\section{Intercultural communicative competence}

The intercultural communicative competence (ICC) is defined by Byram \& Zarate (1997) as the comprehension and consciousness of the socio-cultural aspects that not only cover the use of language and it's discourse. It is complemented by Tarone and Swain (1995) as "the receptiveness of the participants of a speech community to model their speech according to the context in which they are immersed".

Other authors such as Bachman (1990) and Savignon (1983; cited in Jaramillo, 2015) define the intercultural communicative competences as

the speaker's ability to interact effectively with people from other cultures that he/she recognizes as being different from his/her own. It is understood as the ability to cope with one's own cultural background in interaction with others. (p. 14)

In this way, intercultural communicative competence is tightly integrated with learning and aims to integrate learning a language not only to communicate but also support cultural acceptance to enhance diversity and enrich cultural expressions in different contexts of society.

Intercultural communicative competence encodes the main function of learning a foreign language, which is performing speech acts in different scenarios without using ambiguous language, by having in mind the cultural aspects immersed in a context to build cross cultural communication and purposeful knowledge between individuals and communities around the world. This is why Byram et al. (2002) classified the differential factors in intercultural communication.
In recent times, some authors gathered definitions and visions of what intercultural communicative competence means and how it can be defined and its main components. Now, one of the most recognize visions about it is the one given by Deardorff (2006) and it proposes a model of intercultural competence based on the highest rated components of ICC given by the experts and based on theory.

There are two distinctive appreciations of the model. One is the pyramid model that shows how maturing certain aspects of ICC are sustained by dependent elements into the same model. Starting from the bottom, mandatory attitude with its skills and the corresponding knowledge and comprehension required to follow a desired internal outcome which is causaIly linked with the desired external outcome as shown in figure 1. They all conform the phases, attitudes and skills that usually along the process of developing/fostering ICC move from personal level (attitude) to interpersonal/interactive level (outcomes) likely with the degree of ICC that depends on the acquisition a degree of those elements.

Last but not least, Alvino (2008) reflected on the importance of learning and teaching intercultural communicative competences: "It promotes new communication strategies in someone else's terms, transforming one's habitual view of the world" (p.12). This author leads learners to face or deal with how they perceive, conceptualize and express the world being aware of culture and persuading beneficial mutations to old cultural constructs. To do so, different means are used nowadays to support this competence, as a clear example, technology leads some cultural mutations because this means modifies the way people interact and expose their cultures thought a variety of languages, setting through these a hybrid construction about others diverse culture. 


\section{Concerns about the implementation of ICC}

According to Canale \& Swain (1980), with the inclusion of the communicative approach in English language teaching in the 1980s, the teaching of culture is considered an especially important aspect of language teaching and in foreign language curriculum. This assumption was done due to the fact that communication involves the inclusion of values because students might gain insight into the values and meanings of the foreign culture (Byram \& Morgan, 1994).

In this context, De Mejia (2004) emphasizes on the role of teachers because teachers are not only in charge of teaching certain grammatical structures or large list of words. When teaching a foreign language, teachers are also in charge of helping their learners to go further and acquire additional competences such as the cultural ones because they mediate between both cultures.

Somehow, teachers are the intercultural bridge between two or more different worlds of speech and views of language. Teachers need to be capable to mediate between, learners' insights about a new culture and their own in the EFL classroom. This interaction determines one way or another how EFL learners interact with others coming from other cultures that can be encountered in the same EFL classes. Teachers need to modify their vision of teaching in order to contribute to cultural learning development on their learners by being impartial through its teaching practice; it is one of the main challenges EFL teachers are facing today.

Barletta (2009, p. 143) states that teachers have a limited notion of culture and culture teaching. Due to teacher's misconception in the field of intercultural competences, the teaching of culture has occupied a secondary place in the English classroom. However, it is required to integrate language and culture in order to develop an assertive development of communicati- ve competence. For that reason, it is important to investigate the notion of ICC that teacher in the close context has and the way they perform its knowledge in the English classroom.

\section{Relationship between language and culture}

The relationship between language and culture has changed in immeasurable dimensions and it takes a wider degree of study and complexity. The purpose of any language learning is no longer related to merely the acquisition of communicative competence in a foreign language. It should go beyond. Consequently, teachers are entitled to discriminate, value, portrait and teach intercultural communicative competence in English foreign language lessons in different educational contexts.

To describe the nature of a teacher's situation, when teaching a foreign language, it is fundamental to set a context. In our country ICC is relevant because of the introduction of the Common European Framework of Reference for Languages by the Council of Europe CEFR (2001) into the Colombian bilingualism law, which standards give much more importance to cultural aspects in foreign language education (Reid, 2015). On other hand, due to the immigration movements that in Colombia have occurred during the last decades, caused by economic, political or social issues, the classroom becomes a place of cultural convergence.

It is important to mention that in the real context of EFL class in Colombia it is easy to find people who are coming from several cultures belonging to the same country and people coming from Anglophone or other foreign cultures as well. In the English classes, according to my own experience, topics related to Anglophone culture are included in the class activities, because it is relevant to know the context of any foreign language to facilitate its understanding and because culture and language keep a close relationship. 
Nowadays, culture and language are still required to be a subject of study. It is imperative to reflect on the way EFL lessons deal with teaching practices and intercultural competence along the English learning process. Barletta (2009) suggests having a clear perspective and a notion related to intercultural views of language and also to develop the intercultural communicative competence. The reason why this author proposes this is because of the basic standards of foreign language competencies in Colombia, proposed by the Ministry of Education. Because this fact shows a dichotomy between what is written on the standards and what is teaching on EFL lessons regarding intercultural competence. Having an intercultural component in the English classes reinforces the idea that it is imperative to familiarize learners with the cultural insight that a language has and make them aware of the real situation they usually face in their educative context.

With this context-dichotomy already explained, the evidence gathered from different studies, as the ones of Reid (2015), Gómez Rodríguez (2015), Hincapie and Guevara (2016), invite to clarify if roles, beliefs and teachers' practices still affect students' views, comprehension and understanding of intercultural insights of a foreign language.

\section{Discussion}

It is necessary to reflect about teachers' performance and the development of the $\mathrm{CCl}$ and the methodology it includes. Traditionally, English classes are thought based on grammatical methodologies, it would be necessary to review the development and use of ICC in order to develop critical thinking in students.

English textbooks usually include intercultural resources such as readings, videos or audios, however, we could reflect on how this information is addressed, that is if students are led to make a much more in-depth analysis of these topics and make connections between the foreign and own culture. On the other hand, it is necessary to review our conception of culture and intercultural competence and verify if we only conceive intercultural competence when we speak about behavior, traditions and customs of English-speaking countries. It is necessary to bear in mind that in the classroom people from different regions of the same country also converge who still share the same language but have different traditions and customs, especially in big cities in the context of current migratory waves.

The current curricular plans to teach English in Colombia have included the promotion and development of the intercultural communicative competence as a vital tool to face global changes and new cultural phenomena. However, the need to improve English curriculums that still focuses the attention on developing the linguistic competence over the social- cultural competence.

As a clear example, the document called "Pedagogical principles and guidelines suggested English curriculum 6th to 11th grades: English for diversity and equity (MEN, 2016) mentioned that "students of Colombian schools are seen as multidimensional and diverse beings, who develop their personality and participate in equal conditions in the teaching-learning processes in English provided by the schools and their environment" (p. 41), by adding another postulate about growing intercultural competence for students through the English language as a tool to do it.

MEN (2016) also affirms that "bilingualism requires intercultural competences and any subject who actively and dynamically participates in a learning process needs to work on the strengthening of both, the mother tongue and in English as a foreign language" (p. 41). Additionally, the document exposed the reason why the intercultural competence is crucial to 
support global citizenship and bilingualism in students: "He shall use in different situations and contexts to approach the new culture and promote processes of respect and valuation of diversity recognizing similarities and differences with his own culture" (MEN, 2016, p. 41).

Additionally, Hernandez \& Samaca (2006) said that thorough teaching culture in Colombia students are could be able to increase tolerance and respect by internalizing other cultures to develop a critical understanding of diversity and culture acceptance. Contrasting this theory, Barletta (2009) asserts that bilingualism does not provide any special guidance for implementing intercultural practices, because the cultural aspect is not widely addressed in the Colombian English Standards, better known as guide 22, in spite of the evident cultural diversity in Colombia.

To conclude, intercultural competences must be promoted in order to tackle possible cultural misunderstandings and develop awareness among a community in general, it also helps to bridge the gap among cultures, avoid stereotypes and misconceptions people usually have about other cultures. On the way we know and accept others, we can have a better understanding of their behavior, respect their traditions and believes and value our own culture. There is a new perspective about those curricular implementations carried out by MEN.

In one way or another, the curriculum proposal is a fact that schools are implementing step by step. To do so, some tools such as books, material, web based training were implemented to support the English teaching and learning and the development of the intercultural competence as well. Technology is also included as a way that leads intercultural interaction by allowing learners to share experiences with people from different cultures and backgrounds. However, there is still much to do and to reflect especially since we are teachers of English who have an active part in the new processes of education in the field of interculturality and the dynamics of globalization.

\section{Bibliographical References}

1. Abrams, Z. I. (2002). Surfing to cross-cultural awareness: using Internet-mediated projects to explore cultural stereotypes. Foreign Language Annals, 35(2), 141-160.

2. Adler, N. (1997). International Dimensions of Organizational Behavior. South-Western College Publishing.

3. Alvino, E \& (Ed.). (2008). Culture in the classroom. Essential teacher journal, 5(4).

4. Bachman, L. F. (1990). Fundamental Considerations in Language Testing. OUP.

5. Barletta, N. (2009). Intercultural competence: another challenge. Profile: Issues in Teacher's Professional Development, 11, 143-158.

6. Bennett, M. (1998). Basic concepts of intercultural communication. Intercultural Press. 
7. Byram, M. \& Morgan, C. (1994). Developing a theory of language-and-culture learning. In Teaching and Learning Language and Culture (p. 4-40). Multilingual Matters.

8. Byram, M., Gribkova, B. \& Starkey, H. (2002). Developing the intercultural dimension in language teaching: A practical introduction for teachers. Council of Europe. http://www.coe.int/t/dg4/linguistic/Source/Guide_dimintercult_En.pdf.

9. Byram, M. \& Zarate, G. (1997). The sociocultural and intercultural dimension of language learning and teaching. Council of Europe.

10. Canale, M. \& Swain, M. (1980). Theoretical basis of communicative approaches to second language learning and testing. Applied Linguistics, 1(1), 1-47.

11. Council of Europe. (2001). Common European Framework of Reference for Language Learning. CE.

12. Deardorff, D. (2006). Identification and Assessment of Intercultural Competence as a Student Outcome of Internationalization. Journal of Studies in Intercultural Education, 10, 241-266.

13. Delors, J. (1996). La educación encierra un tesoro. Correo de la Unesco.

14. De Mejía, A. M. (2004). Bilingual Education in Colombia: Towards an Integrated Perspective. International Journal of Bilingual Education and Bilingualism, 7(5).

15. Fantini, A. \& Tirmizi, A. (2006). Exploring and assessing intercultural competence. World Learning Publications. Paper 1. http://digitalcollections.sit.edu/worldlearning_publications/1

16. Gómez Rodríguez, L. F. (2015). Critical intercultural learning through topics of deep culture in an EFL classroom. Íkala, Revista de Lenguaje y Cultura, 20(1), 43-59 doi: 10.17533/udea.ikala. v20n1a03 Hall, E. T. (1976). Beyond Culture. Garden City.

17. Hall, E. T. (1976). Beyond Culture. Garden City.

18. Hernández, O. \& Samacá, Y. (2006). A Study of EFL Students' Interpretations of Cultural Aspects in Foreign Language Learning. Colombian Applied Linguistics Journal.

19. Hincapie, J. P. \& Guevara, Y. R. (2016). Raising intercultural awareness through speaking tasks in fifth graders classroom project (unpublished master's thesis). Universidad Tecnológica de Pereira, Facultad de Bellas Artes y humanidades. Retrieved April 18, 2018, from http://repositorio.utp.edu.co/dspace/bitstream/handle/11059/7226/4101H659.pdf?sequen$\mathrm{ce}=1$ 
20. Jaramillo, N. (2015). A proposal to improve intercultural communicative competence through videos in an English program of a private university [Ebook]. Universidad Escuela de Ciencias de la Educación. https://repository.icesi.edu.co/biblioteca_digital/bitstream/10906/78766/1/ T00386.pdf

21. MEN. (201\&amp;). Pedagogical principles and guidelines suggested English curriculum 6th to 11th grades: English for diversity and equity. Gobierno de Colombia.

Retrieved April 18, 2018, from:

http://aprende.colombiaaprende.edu.co/sites/default/files/naspublic/Anexo 15

Pedagogical Principles and Guidelines.pdf

22. Kramsch, C. (2001). Context and culture in language teaching. Oxford University Press. MEN. (201\&). Pedagogical principles and guidelines suggested English curriculum 6th to 11th grades: English for diversity and equity. Gobierno de Colombia. Retrieved April 18, 2018 , from: http://aprende.colombiaaprende.edu.co/sites/default/files/naspublic/Anexo 15 Pedagogical Principles and Guidelines.pdf

23. Meyer, M. (1991). Developing transcultural competence: case studies of advanced foreign language learners. In D. Buttjes \& M. Byram (Eds.), Mediating languages and cultures. Multilingual Matters.

24. Paige, R. M., Jorstad, H. L., Siaya, L., Klein, F. \& Colby, J. (2003). Culture learning in language education: A review of the literature. In D. L. Lange \& R. M. Paige (Eds.), Culture as the core: Perspectives on culture in second language learning (pp. 173-236). Information Age Publishing.

25. Reid, E. (2015). Techniques developing intercultural communicative competences in English language lessons. Procedia - Social and Behavioral Sciences, 186, 939-943. https://doi.org/10.1016/j.sbspro.2015.04.011

26. Spencer-Oatey, H. (2008) Culturally Speaking. Culture, Communication and Politeness Theory. 2nd edition. Continuum.

27. Straub, H. (1999). Designing a cross-cultural course. English Forum, 37(3).

28. Tarone, E. \& Swain, M. (1995). A sociolinguistic perspective on second-language use in immersion classroom. Modern Language Journal, 79, 166-178.

http://citeseerx.ist.psu.edu/viewdoc/download?doi=10.1.1.507.3128\&rep=rep1\&type=pdf

29. Unesco. (2013). Intercultural Competences: Conceptual and Operational Framework. Unesco. http://www.unesco.org/new/en/bureau-of-strategic-planning/themes/culture-of-peace-andnon-violence/

30. Wright, S. (1998). The politicization of 'culture'. Anthropology today, 14(1), 7-15. 